\title{
Economics of contracts in African food systems: evidence from the malt barley sector in Ethiopia
}

\author{
Delelegne A. Tefera ${ }^{1,2^{*}}$ and Jos Bijman ${ }^{3}$
}

\author{
*Correspondence: gdele06@gmail. \\ com \\ ${ }^{1}$ European Commission Joint \\ Research Center, Ispra, Italy \\ ${ }^{2}$ Department of Agricultural \\ Economics, Hawassa University, P.O. \\ Box 05, Hawassa, Ethiopia \\ Full list of author information is \\ available at the end of the article
}

\begin{abstract}
Foreign direct investment (FDI) facilitates modernization of domestic agri-food systems in emerging economies through increased use of vertical coordination. This paper sheds lights on how international brewer investments in African food systems affect smallholder market participation and value chain development. In particular, we analyze the impact of contracts among malt barley producers in Ethiopia. Using cross-sectional survey data, we employ inverse probability-weighted regression adjustment (IPWRA) and propensity score matching (PSM) techniques to analyze the economic impact of contracting. We find that contrary to popular belief, contracting has positive and significant impact on malt barley production, intensification, commercialization, quality improvement, and farm gate prices, ultimately resulting in increased net income and spillover into the productivity of other food crops.
\end{abstract}

Keywords: Contract, Africa, Food systems, Impact evaluation, Treatment effect, IPWRA, Ethiopia

\section{Springer Open}

\section{Introduction}

Smallholder agriculture remains important for economic development in sub-Saharan Africa (SSA) and produces about $80 \%$ of the food consumed in the region (FAO 2013b). In recent years, food systems in this region witnessed major changes and rapid structural transformation. The increase in urbanization, rising incomes, industrialization, a burgeoning middle class, and globalization have led to the emergence of modern supply chains, including modern food retail (Maertens and Swinnen 2012; Minten et al. 2016; Reardon et al. 2009; Verhofstadt and Maertens 2013). These developments have resulted in changes in the food production process, vertical coordination, and dominance of food processors (Swinnen and Maertens 2007).

Increased vertical coordination and modernization in food systems present market opportunities for smallholders (Dries et al. 2009; McCullough et al. 2008; Verhofstadt and Maertens 2013). However, smallholder access to modern chains is limited due to several constraints. Smallholders are unable to comply with the stringent standards (safety, quality, and reliability) and technical requirements. They are often constrained

(c) The Author(s). 2021 Open Access This article is licensed under a Creative Commons Attribution 4.0 International License, which permits use, sharing, adaptation, distribution and reproduction in any medium or format, as long as you give appropriate credit to the original author(s) and the source, provide a link to the Creative Commons licence, and indicate if changes were made. The images or other third party material in this article are included in the article's Creative Commons licence, unless indicated otherwise in a credit line to the material. If material is not included in the article's Creative Commons licence and your intended use is not permitted by statutory regulation or exceeds the permitted use, you will need to obtain permission directly from the copyright holder. To view a copy of this licence, visit http://creativecommons.org/licenses/by/4.0/. 
by lack of access to improved technology, low bargaining power, and high transaction costs (Poulton et al. 2010).

Contract farming has been presented as a possible solution to raising productivity and linking smallholders in the emerging modern chains (FAO 2013a). Many scholars have studied the increasing prevalence of contract farming arrangements (CFAs) in the dynamic food systems (Bellemare 2015; Minot and Sawyer 2016; Oya 2012; Wang et al. 2014b). Most of these studies claim that CFAs promote smallholder linkages to highvalue markets and increase farm income. Yet, there is also evidence that participating in a CFA has a negative association with farm income (Michelson et al. 2012; Narayanan 2014; Wendimu et al. 2016).

Most studies have focused on supply chains of high-value products (e.g., vegetables), traditional cash crops (e.g., coffee, tea, cocoa), and industrial commodities (e.g., cotton, palm oil, and rubber), mainly destined for international markets (Minot and Sawyer 2016; Otsuka et al. 2016). The empirical evidence on the impact of CFAs in domestic food systems is sparse, with the exception of Maertens and Vande Velde (2017). In this paper, we seek to fill the knowledge gap by exploring the impact of CFAs between foreign investors and smallholders on economic performance of malt barley farmers in Ethiopia. Understanding the effectiveness of CFAs in the emerging malt barley sector in Ethiopia is particularly relevant because the country aims at expanding the domestic malt barley production to cut the import bill and to increase smallholder commercialization. The paper also discusses how foreign direct investment in developing countries-in Africa in particular-affects modernization of domestic food systems.

The main objective of this paper is to analyze the impact of CFAs on production, commercialization, and farmer income within a local food system. Specifically, we seek to address: (i) What factors determine farmers' participation in malt barley CFAs? (ii) How do CFAs improve production, crop yield, product quality, and commercialization and prices in malt barley chains? (iii) How do CFAs improve malt barley farm income? The study is based on cross-sectional survey data and uses inverse probability-weighted regression adjustment (IPWRA) and propensity score matching (PSM) techniques to analyze the impact of CFAs.

The rest of the paper is organized as follows. The next section provides a short review of the literature on CFAs in emerging economies. In the "Multinationals and CFAs in Ethiopian food systems" section, we present a brief account of the Ethiopian malt barley chain and describe the process of vertical coordination. The "Methodology" section describes the methodology. The "Empirical results" section presents the empirical results. The "Discussion" section discusses and puts the results into perspective. The "Conclusions" section concludes.

\section{A review of the literature}

Various empirical studies investigated the prevalence and effectiveness of CFAs in food systems of developing economies. We present a short review of these studies using the following perspectives: (a) the prevalence in the use of CFAs; (b) which farmers participate in CFAs; (c) the welfare impacts of CFAs; and (d) the organization of the contract and the role of intermediaries.

Contract farming can be defined as "agricultural production carried out according to an agreement between farmers and a buyer which places conditions on the production 
and marketing of the commodity" (Minot 1986 p. 2). Agreements are made in advance and often on the volume, quality, time of delivery, use of inputs, and the price that will be offered. The recent development in food systems of emerging economies has witnessed a rapid expansion in the use of contract farming (Jia and Bijman 2014). The expansion of high-value products, improvement in food processing, consolidation in retail markets, and increased demand for quality and food safety have induced the rise in CFAs (Minot and Sawyer 2016; Otsuka et al. 2016).

In studying the implications of CFAs, it is crucial to understand which factors determine smallholders' decision to enter in a CFA. Participation in a CFA depends on a number of demographic and socio-economic factors. Several studies conclude that the farmer's level of education has a negative effect on the likelihood of participation in a CFA (Maertens and Vande Velde 2017; Miyata et al. 2009; Simmons et al. 2005; Wainaina et al. 2014), whereas others find a positive effect (Mishra et al. 2016). There are also studies that show that education does not affect CFA participation (Bellemare 2012; Girma and Gardebroek 2015). Many studies conclude that the farmer's age has a negative effect on participation in a CFA (Bellemare 2012; Maertens and Vande Velde 2017; Simmons et al. 2005), implying that younger farmers are more likely to join a CFA.

Several empirical studies have found that farm size positively determines farmers' participation in CFAs (Bellemare 2012; Mishra et al. 2016), whereas other studies conclude that farm size is not an important determinant (Maertens and Vande Velde 2017; Miyata et al. 2009; Wainaina et al. 2014). Thus, the empirical evidence on the effect of farm size is inconclusive. Access to public institutions such as extension services (Girma and Gardebroek 2015) and credit (Ma and Abdulai 2016; Simmons et al. 2005) determines farmers' likelihood of participation in CFAs. Ownership of a mobile phone has also been found to affect CFA participation (Kumar et al. 2016; Mishra et al. 2016). Finally, distance to the market has a positive and significant effect on CFA participation in the studies of Kumar et al. (2016) and Maertens and Vande Velde (2017), while Wainaina et al. (2014) found a negative effect.

There are numerous empirical studies on the impact of CFAs (Andersson et al. 2015; Barrett et al. 2012; Bellemare 2012; Bolwig et al. 2009; Briones 2015; Girma and Gardebroek 2015; Mishra et al. 2016; Simmons et al. 2005; Wang et al. 2014a). These studies show that participating in a CFA improves the income of farmers who have chosen to participate. There is also empirical evidence on effects other than income. For example, Maertens et al. (2012) show the implications of CFAs for gender, Dedehouanou et al. (2013) show the impact on subjective well-being in Senegal, and Minten et al. (2009) document implications for food security and technology adoption in Madagascar. Yet, most of these studies focused on high-value products, industrial crops, traditional cash crops, and seeds production. With the exception of Maertens and Vande Velde (2017), there are no rigorous empirical studies on the impact of CFAs in grain and staple food chains. Maertens and Vande Velde (2017) have studied the impact of CFAs in the Beninese rice sector, and document positive effects of CFAs on intensification of rice production, commercialization of rice, and household income.

A recent discussion in the CFA literature concerns the role of intermediaries such as producer organizations (POs) and NGOs (Briones 2015; Roy and Thorat 2008; Royer et al. 2017). POs can reduce transaction costs in contracting between an agribusiness 
firm and a large number of dispersedly located small farms. POs can facilitate the supply of inputs to contracted farmers and can improve their bargaining power. Contracts are often between a processor and a PO; a farmer must first be a member of the PO before she can enter the CFA. In such arrangements, POs ensure the quantity, quality, and timely delivery of products. However, some authors have argued that POs become selective when achieving this business objective, and resource-poor farmers may be left out of membership (Bernard and Spielman 2009; Bijman et al. 2016).

Several empirical studies on export-oriented chains found a positive effect of CFAs on the income and productivity of the contracted farmer. Minot and Sawyer (2016) conclude from their review of the literature that income effects of CFAs range between 25 and 75\%, while Ton et al. (2018), in their meta-analysis, found an income effect of $38 \%$. However, the literature falls short when it comes to CFAs in domestic grain and staple food chains. Our study seeks to fill this gap by analyzing the economic impact of CFAs in the malt barley sector in Ethiopia.

Our study is particularly relevant with respect to the literature on CFAs in Ethiopia, where the development and impact of CFAs are a mixed story. CFAs are still relatively new in Ethiopia. There are only a few recent studies (Abebe et al. 2013; Girma and Gardebroek 2015), which show that CFAs improve farmer income in export-oriented chains. In addition, there is also evidence against CFAs, as Wendimu et al. (2016) show that participation in CFAs significantly reduces farm income and asset stocks of farmers in the Ethiopian sugarcane industry.

We hypothesize that CFAs assure markets for smallholder producers and potentially lead to improvement in farm income and productivity. We expect that farmers with contracts earn a higher income than farmers without contracts, because the buyer (the brewery) introduces improved barley varieties, provides key inputs and technical assistance, and facilitates logistics and coordination in the supply chain. In return, buyers demand higher quality and they are willing to pay a higher price.

\section{Multinationals and CFAs in Ethiopian food systems}

Ethiopia is the largest producer and consumer of barley in the African continent (Rashid et al. 2015). Barley is a smallholder crop and currently more than four million smallholders produce barley and derive their livelihood from the barley value chain (CSA 2015). Nationally, two types of barley are grown: food barley for home consumption and malt barley for brewing. Driven by rising income and increased urbanization, per capita beer consumption in Ethiopia has grown rapidly at an annual rate of $20 \%$ (Tefera 2017). This promising beer market has attracted beer multinationals, including Heineken, Diageo, and Bavaria. These breweries have invested both in beer brewing and in local sourcing of malt barley. Companies used CFAs to organize their supply chains and source malt barley. The introduction of CFAs for the production of malt barley started in 2013 in the study area. In fact, breweries have been engaged in contract farming practices before 2013 in other malt barley production areas. Currently (2020), in addition to Diageo and Heineken breweries, other maltsters (AMF, Soufflet, and Boortmalt) and Saint George brewery are engaged in contract production of malt barley in the Arsi region which includes the study area.

The appearance of international brewers in the malt barley value chain has increased the annual demand for malt barley, on average at a rate of $20 \%$ (Tefera 2017). This has 
affected the malt barley sector by generating new market opportunities for smallholders, reducing price volatility, ensuring reliable supply chains, and cutting the import bill, thus saving foreign currency for the government. Heineken, Diageo, and the Assela Malt Factory (AMF) are engaged in the sourcing of malt barley from smallholders in the Arsi highlands (Fig. 1). We have identified two types of malt barley supply chains: the conventional and the modern chain. The co-existence of the conventional and modern chains has led to major changes in barley production and marketing. The conventional chain starts from smallholders selling malt barley to local traders and retailers. Transactions are governed by market prices negotiated on the spot. AMF is the dominant aggregator of malt barley from local traders.

The modern chain, however, is driven by breweries and characterized by vertical coordination. In this chain, a strict requirement for quality and quantity is arranged together with price premiums. Written contracts are used to safeguard these agreements. The modern chain is characterized by few intermediaries, supply chain management (control of quality and quantity), and technology transfer. To integrate smallholders in

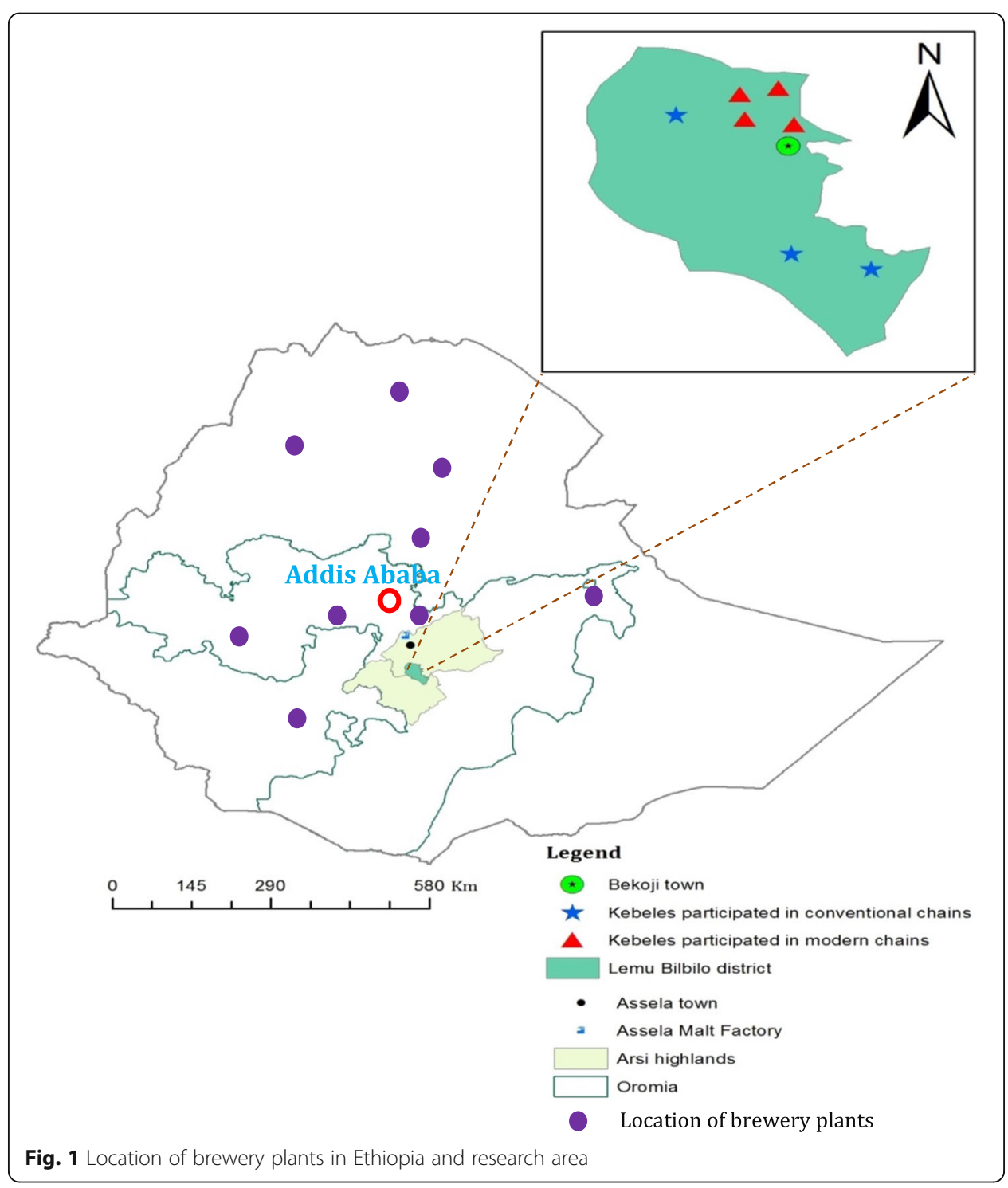


the modern chain, companies introduced on-farm training in good agricultural practices and quality upgrading. Companies hired and employed field experts (agronomist) and business advisors to coach and train farmers. Field experts follow up and supervise contracted farmers and their plots for proper application of the service package.

For contracting with smallholders, companies have sub-contracted NGOs to select and organize farmers, select POs, facilitate input supply, and provide technical assistance. POs play an intermediary role through distributing modern inputs, arranging logistics, and aggregating malt barley. As part of the contractual agreement, brewers provide improved seeds, fertilizers, and pesticides on pre-financing basis to smallholders. In return, farmers deliver malt barley that fulfills the quality requirements. The companies pay quality-based price premiums.

\section{Methodology}

\section{Data collection}

Data were collected in the main barley region of Ethiopia, the Arsi highlands (Fig. 1). The Arsi highlands consist of many districts that are known for the production of barley. We purposively selected Lemu Bilbilo District for three reasons: it has a high production of malt barley; it has seen the appearance of foreign breweries in the local sourcing of malt barley; and it already has multiple cases of CFAs between breweries and farmers.

To investigate the economic impacts of CFAs in the malt barley sector, we used primary survey data. We conducted the survey on a total of 262 farm households in different villages of Lemu Bilbilo District. The survey was carried out from April to May 2015. A multi-stage sampling procedure was used for the selection of a targeted sample. First, four POs with contracts were selected from four different villages in the district (Fig. 1). From this group, we randomly selected a total of 110 households (treatment group). Second, a total of 152 non-contract farmers (control group) were randomly selected from three other villages in the same district. In the district, most of the systemic issues (local policies, culture, demographic, socio-economic, and agro-ecology) are similar which could help us to control the structural differences between contract (treatment) and non-contract farmers (control group). All farmers are barley producers. Non-contract farmers could still be PO members. However, in the final analysis, only 258 households were used, as four questionnaires from the non-contract group were incomplete.

A structured questionnaire was prepared and carefully administered to gather household-level primary data. Well-trained enumerators collected the data in face-toface interviews. Data were collected on household demographic characteristics, sources of livelihoods, conditions of food security, off-farm employment, asset ownership, types and quantities of crops produced, sale of crops and output prices, household access to credit, markets and extension services, and membership of irrigation associations and POs. Moreover, the data included information on types and volume of inputs used in malt barley production, inputs supply arrangements, costs of inputs (hired labor, fertilizers, pesticides, and improved seeds), quality improvement practices, quality grading, malt barley prices, market outlets, and overall production and marketing challenges in the value chain. 


\section{Econometric approach}

In terms of methodological techniques used, the early work on CFAs simply compares mean income of contract and non-contract farmers to measure the contract effect (e.g., Singh 2002). While these studies find that CFAs have a positive income effect, the results are subject to bias. Other studies used a selection correction empirical strategy to measure the impact of CFA (e.g., Bolwig et al. 2009; Miyata et al. 2009). More recently, studies have used propensity score matching (PSM). However, PSM is usually built on the strong assumption that observable characteristics determine selection into treatment and control groups. Thus, matching estimators are prone to selection bias, which is caused by unobservable heterogeneity (Caliendo and Kopeinig 2008). To this end, we used inverse-probability-weighted-regression-adjustment estimator (IPWRA) to address these issues in PSM and to measure the average contract effect. IPWRA provides efficient estimates by allowing the modeling of both the outcome and the treatment equations (StataCorp 2017).

Based on literature, we selected the following seven performance indicators: (1) malt barley yield, measured in quintal per hectare; (2) malt barley selling price, measured in Ethiopian birr (ETB) per quintal; (3) cost of inputs for malt barley production, measured in ETB per hectare; (4) share of malt barley sold, measured in percentage (i.e., malt barley sold/malt barley produced ratio); (5) net income from malt barley production, measured in ETB per hectare (calculated as the difference between gross income and malt barley-related variable costs); (6) product quality; measured in a scale (i.e., farmers stated quality on a 3-point Likert scale; ranging from $1=$ low and $3=$ high); and (7) gross income from other crops, measured in ETB per hectare (calculated as volume other crops produced $\times$ selling prices).

Participation in a CFA is likely not randomly distributed among malt barley farmers; hence, we include a large set of observable farm and farmer characteristics. These include various covariates selected on the basis of theory and previous studies (see the "A review of the literature" section). We include the following covariates: age and education of the household head, available family labor, number of people in the household, land, and livestock ownership, malt barley-cultivated area, farming experience, proportion of income earned in off-farm activities (as proxy for off-farm employment), distance to markets, mobile phone ownership, credit received from microfinance, and extension contact (Table 1). Using these covariates, a logit model was fitted with the binary treatment variable (CFA status of the farmer) as selection variable, conditional on the baseline characteristics of both the treatment (contracted) and the control group (non-contracted). From this, propensity scores, i.e., the conditional probability of assignment to a treatment given their baseline characteristics, are predicted.

PSM and IPWRA minimize selection bias on outcome variables by adjusting outcomes and selection based on observable variables. PSM tries to adjust selection based on observables. IPWRA tries to adjust both selection and outcomes based on observables. This makes the IPWRA a more reliable estimator than other estimators, including PSM, inverse probability weighted (IPW) and regression adjustment (RA). Nevertheless, all treatment effect models are still prone to selection bias despite differences in extent of minimizing the effect of unobservable effects among themselves (StataCorp 2017). The only models that fully control selection bias are endogenous average treatment models consisting of endogenous switching, Heckman, and instrumental 
Table 1 Characteristics of contract and non-contract malt barley farmers

\begin{tabular}{|c|c|c|c|c|c|}
\hline Variables & Description & $\begin{array}{l}\text { Total } \\
\text { sample }\end{array}$ & Contract & $\begin{array}{l}\text { Non- } \\
\text { contract }\end{array}$ & Diff. \\
\hline \multicolumn{6}{|c|}{ Socioeconomic characteristics } \\
\hline Age & Household head $(\mathrm{HH})$ age in years & 44.32 & 44.55 & 44.16 & 0.39 \\
\hline Family size & Number of people in the household & 6.35 & 6.21 & 6.45 & -0.24 \\
\hline $\begin{array}{l}\text { Family active } \\
\text { labor }\end{array}$ & Family members $15-65$ years age & 3.87 & 3.81 & 3.91 & -0.1 \\
\hline Education & $\mathrm{HH}$ education level in years & 5.14 & 5.96 & 4.54 & $1.42^{* * *}$ \\
\hline Off-farm income & $\mathrm{HH}$ share of off-farm income (\%) & 4.51 & 3.18 & 5.51 & $-2.32^{*}$ \\
\hline Innovativeness & $\mathrm{HH}$ innovativeness in farm business ${ }^{\mathrm{a}}$ & 3.30 & 4.06 & 2.73 & $1.33^{* * *}$ \\
\hline Entrepreneurship & $\mathrm{HH}$ entrepreneurial skills ${ }^{\mathrm{a}}$ & 3.13 & 3.77 & 2.66 & $1.10^{* * *}$ \\
\hline $\begin{array}{l}\text { Mobile } \\
\text { ownership }\end{array}$ & HH mobile phone ownership (0-1) & 0.70 & 0.81 & 0.62 & $0.19^{* * *}$ \\
\hline \multicolumn{6}{|c|}{ Malt barley cultivation } \\
\hline Farm size & $\mathrm{HH}$ landholding size in hectare & 2.75 & 2.70 & 2.79 & -0.09 \\
\hline Malt barley area & Malt barley cultivated area in hectare & 0.74 & 0.79 & 0.69 & 0.10 \\
\hline Experience & Malt barley farming experience in years & 20.29 & 20.69 & 20.0 & 0.69 \\
\hline Total livestock & Total livestock ownership in TLU & 11.09 & 14.45 & 8.59 & 5.85 \\
\hline \multicolumn{6}{|c|}{ Access to public institutions } \\
\hline Savings & $\mathrm{HH}$ saving in last 12 months (0-1) & 0.59 & 0.74 & 0.48 & $0.25^{* * *}$ \\
\hline Extension contact & $\begin{array}{l}\mathrm{HH} \text { access to public extension service } \\
(0-1)\end{array}$ & 0.53 & 0.67 & 0.42 & $0.24^{* * *}$ \\
\hline Access to credit & $\begin{array}{l}\mathrm{HH} \text { credit received from microfinance } \\
(0-1)\end{array}$ & 0.14 & 0.20 & 0.09 & $0.10^{* * *}$ \\
\hline $\begin{array}{l}\text { Distance to } \\
\text { market }\end{array}$ & $\begin{array}{l}\text { Distance to market }(\mathrm{km}) \text { in one way } \\
\text { walk }\end{array}$ & 7.93 & 5.59 & 9.67 & $-4.08^{* * *}$ \\
\hline \multicolumn{6}{|c|}{ Access to collective institution } \\
\hline Iddir membership & $\mathrm{HH}$ membership to Iddir in year & 19.37 & 19.81 & 19.04 & 0.77 \\
\hline PO membership & HH membership to POs (0-1) & 0.72 & 1.00 & 0.52 & $0.47^{* * *}$ \\
\hline $\begin{array}{l}\text { Debo } \\
\text { membership }\end{array}$ & HH membership to Debo in year & 20.09 & 20.62 & 19.66 & 0.96 \\
\hline \multicolumn{6}{|c|}{ Performance indicators } \\
\hline Yield & Malt barley yield (quintal/hectare) & 20.03 & 21.67 & 18.80 & $2.87^{* * *}$ \\
\hline Price & Malt barley selling price (ETB/qt) & 906 & 1013 & 829 & $184^{* * *}$ \\
\hline Share sold & Malt barley sold to produced ratio & 0.59 & 0.71 & 0.51 & $0.21^{* * *}$ \\
\hline Cost & Cost of malt barley production (ETB/ha) & 4442 & 4803 & 3994 & $809^{* * *}$ \\
\hline Product quality & HH stated malt barley quality (scale 1-3) & 2.39 & 2.80 & 2.08 & $0.71^{* * *}$ \\
\hline Net income & Malt barley net income per ha (ETB/ha) & 13604 & 15532 & 10990 & $4542^{* * *}$ \\
\hline $\begin{array}{l}\text { Other crop } \\
\text { income }\end{array}$ & Income from other crops sale (ETB/ha) & 9952 & 13653 & 7202 & $6452^{* * *}$ \\
\hline $\mathrm{N}$ & & 258 & 110 & 148 & 258 \\
\hline
\end{tabular}

Source: Field survey, 2015; ${ }^{* *} P<0.01,{ }^{* *} P<0.05,{ }^{*} P<0.10$; note: ${ }^{\text {a }}=$ Likert scale variables with 5 scales; $^{\text {b }}=$ tropical $^{*}$ livestock unit to describe livestock numbers of various species as a single unit

variable methods. However, as our data could not fit the endogenous treatment models, we used PSM and IPWRA in our analysis.

PSM reduces the selection bias through employing counterfactuals that control all other factors but treatment (Rosenbaum and Rubin 1983). The essential mechanism of PSM is to find comparison groups (non-contracted farmers) that are similar to the 
treated in all relevant pre-treatment characteristics. These two balanced groups are created based on their estimated propensity scores. Following Caliendo and Kopeinig (2008), let $\mathrm{W}_{\mathrm{i}}$ be a binary treatment variable that equals one if a farmer participates in a CFA, and zero otherwise. The potential outcomes of the CFA are represented by $\left(W_{i}\right)$ for each household i. The average treatment effect on the treated (ATT) is expressed as:

$$
\tau A T T=E(\tau \mid \mathrm{W}=1)=\mathrm{E}[Y(1) \mid \mathrm{W}=1]-\mathrm{E}(\mathrm{Y}(0) \mid \mathrm{W}=1]
$$

Where $E[Y(1) \mid W=1]$ is the expected outcome value for contracted farmers; $E[Y$ (0) $\mid \mathrm{W}=1]$ is the expected outcome value for contracted farmers if they had not been contracted. $E[Y(0) \mid W=1]$ is the counterfactual and not-observed, as we need a proper substitute to estimate ATT. In this case, PSM helps to construct the counterfactual from the non-contracted farmers. In doing so, we invoke the conditional independence assumption (CIA) and the common support assumption to control the selection bias problem (Caliendo and Kopeinig 2008). The non-confoundedness assumption (i.e., CIA) ensures that selection into treatment is only based on observable covariates, which is a strong assumption. We address this assumption using the bounding approach (Rosenbaum 2002). The common support condition ensures that farmers with similar observable covariates have a positive probability of being both participant and non-participant (Caliendo and Kopeinig 2008). We check this assumption using balancing properties and a density distribution histogram. If CIA holds and there is overlap between contract and non-contract groups, the PSM estimator for $\mathrm{T}_{\text {ATT }}$ is given as:

$$
{ }_{A T T}^{P S M}=E_{p(x) \mid W=1}\{\mathrm{E}[\mathrm{Y}(1) \mid \mathrm{W}=1, \mathrm{p}(\mathrm{x})]-E[Y(0) \mid W=0, \mathrm{p}(\mathrm{x})]\}
$$

Where $\mathrm{p}(\mathrm{x})$ is the predicted propensity score from the logit model. We used different methods to match similar contract and non-contract farmers. We apply nearest neighbor matching (NNM), radius matching (RM), and kernel-based matching (KBM) as the main ATT estimation methods (Becker and Ichino 2002; Caliendo and Kopeinig 2008). However, the PSM is problematic if the CIA is not met. As a result, a double robust IPWRA estimator is used as our main method for treatment effect estimates.

IPWRA provides efficient estimates by allowing the modeling of both the outcome and the treatment equations (StataCorp 2017). This allows us to control for selection bias at both the treatment and outcome stages. Thus, the IPWRA estimator has the double-robust property, which means that only one of the two models is correctly specified to consistently estimate the impact (Bang and Robins 2005; StataCorp 2017). One could say that regression adjustment (RA) concentrates on outcomes, and inverse probability weight (IPW) focuses more on treatment in calculating treatment effects. IPWRA estimators use probability weights to obtain outcome regression parameters and the adjusted outcome regression parameters are used to compute averages of treatment-level predicted outcomes. The IPWRA method has recently been used by Kebebe (2017) in an impact evaluation of dairy technology adoption in Ethiopia. 


\section{Empirical results}

\section{Comparison of contract and non-contract farms}

Household characteristics

In Table 1, we present summary statistics for contract and non-contract farmers. Contract farmers are, on average, more educated than non-contract farmers. Contract and non-contract farmers are also significantly different in access to a mobile phone, access to extension services, access to savings, access to credit, and to PO membership. In addition, the mean distance to the market is lower among the contract farmers. All contract farmers are member of a PO, which reflects the fact that organizing themselves in groups is a precondition for engaging in the CFA.

\section{Malt barley production}

Smallholders use various inputs to produce malt barley. The main inputs include fertilizers, pesticides, and improved seeds. Farmers have access to improved seeds from buyers (i.e., breweries) and other sources. Another input category is labor, whereby farmers mostly use family labor and some additional hired labor during the peak farming season. Table 1 presents the mean comparison of the various outcome indicators. On average, contract farmers produce more malt barley $(17 \mathrm{qt})$ than the non-contract farmers (12qt). The average yield is also $15 \%$ higher than that of non-contract farmers. Contract farmers receive a $22 \%$ higher average price and commercialize on average $21 \%$ point more of their malt barley production than non-contract farmers. In addition, contract farmers have a $20 \%$ higher average cost of production per ha than noncontract farmers. Finally, farmers participating in CFAs obtain on average $42 \%$ and $41 \%$ higher malt barley gross income and net incomes per ha, respectively, than those who do not participate.

\section{Factors determining CFA participation}

A farmer's decision to participate in a CFA could be conditioned by demographic variables, socio-economic characteristics, and access to assets. We used a logit model to estimate the parameters. Based on the pseudo- $\mathrm{R}^{2}(0.359)$, which is high and significant at $1 \%$ level, the covariates clearly explained the participation probability. In addition, the model indicates that $78 \%$ of the sample observations is correctly predicted.

Specific variables were selected based on theory and previous empirical research. From the selected covariates, six were significant in influencing a farmer's decision to enter a CFA. These are education level, off-farm income, distance to markets, having a mobile telephone, access to public extension service, and receiving microfinance credit (Table 2). All these covariates positively affect the probability of farmers' participation in CFAs except off-farm income and distance to markets.

The results show that education of the household head has a positive and significant effect on participation in a CFA. Education facilitates managerial capacity, farmers' ability to make informed decisions, and to be able to comply with quality requirements. Having a mobile phone increases farmers' likelihood to participate in a CFA by enhancing access to information and effective communication. Farmers having received credit from rural microfinance institutes are more likely to participate in a CFA. Results further show that access to government extension services is positively correlated to CFA 
Table 2 Determinants of farmers' decision to participate in CFA

\begin{tabular}{lllll}
\hline CFA participation & Coefficient & Std. error & $\mathbf{z}$ & $\mathbf{P}>|\mathbf{z}|$ \\
\hline Age & -0.006 & 0.036 & -0.18 & 0.855 \\
Family size & -0.004 & 0.116 & -0.04 & 0.968 \\
Family active labor & -0.086 & 0.182 & -0.48 & 0.634 \\
Education & 0.144 & 0.058 & 2.48 & $0.013^{* *}$ \\
Farm size & 0.008 & 0.110 & 0.07 & 0.942 \\
Malt barley area & 0.331 & 0.313 & 1.06 & 0.290 \\
Farming experience & 0.051 & 0.033 & 1.51 & 0.130 \\
Total livestock & 0.006 & 0.013 & 0.47 & 0.638 \\
Share of off-farm income & -0.041 & 0.019 & -2.16 & $0.031^{* *}$ \\
Distance to markets & -0.392 & 0.067 & -5.82 & $0.000^{* * *}$ \\
Mobile ownership & 1.287 & 0.441 & 2.91 & $0.004^{* * *}$ \\
Credit received from microfinance & 1.283 & 0.499 & 2.57 & $0.010^{* * *}$ \\
Extension contact & 1.179 & 0.347 & 3.40 & $0.001^{* * *}$ \\
_cons & -0.589 & 1.352 & -0.44 & 0.663 \\
Summary statistics & & & \\
$\quad$ Pseudo $R^{2}=0.359$ & Percentage of correct prediction $=77.95 \%$ & \\
$\quad$ Model $X^{2}=124.65^{* * *}$ & Number of observations $=254$ & & \\
Log likelihood $=-110.883$ & & &
\end{tabular}

participation, while off-farm income is negatively correlated. Our results also show that distance to markets negatively influences the likelihood of CFA participation. This is plausible, as companies prefer farms near the road or the market center for logistic reasons and reduction of transaction costs in monitoring and provision of technical assistance.

Finally, variables representing access to productive assets such as available family labor, farm size, malt barley area, and total livestock, did not affect farmers' decisions to participate in CFAs. This implies that small and large farms both participate in contracting. Though not included in the model, membership to a PO is a pre-requisite to breweries' CFAs.

Impact of smallholder participation in CFA

\section{Estimating propensity scores}

We estimated the propensity scores for the contract and non-contract farmers using the logit model. The magnitude of the propensity score ranges between 0 and 1 ; the higher the score, the more likely that the farmer would participate in CFA. The predicted propensity scores for contract farmers range from 0.030 to 0.990 with a mean of 0.660 , and from 0.001 to 0.926 for non-contract farmers with a mean of 0.246 .

Based on these predicted propensity scores, we test the common support assumption. Using the rules of minima-maxima (Caliendo and Kopeinig 2008), the common support assumption is satisfied in the region of 0.030-0.926. The common support region is also examined using the density distribution for the two groups of treated (contract) and untreated (non-contract) (Fig. 2 in the Appendix shows the line graphs and histogram). 
The overlap in the distribution of the propensity scores for contract and non-contract farmers is also visually checked: the result suggests that there is a high chance of obtaining good matches.

\section{Estimating impacts of CFA}

We then estimated the average treatment effects on the treated (ATT), which is the mean impact that participation in CFA has on malt barley farmers along a number of outcome variables. The result for IPWRA estimates is presented in Table 3. We found positive and significant impact of participation in CFAs on all the selected outcome indicators. We find that the results are quite robust, with the same signs and significance levels and comparable point estimates among the different matching algorithms of PSM (Table 4).

(a) Malt barley yield, quality, and intensification We find that CFAs lead to using more inputs per ha in malt barley production, which is evidenced by a higher variable cost per ha (Table 3) and a higher quantity of fertilizers used (Table 5 in the Appendix). We also find that CFAs lead to larger malt barley yields and higher quality. On average, a CFA increases input costs by about 946 ETB per ha, which is an increase of $24 \%$ compared to the average input costs per ha in the research area. Yields are found to increase by 3.34 quintal per ha or $18 \%$ in comparison to the average yield in the Arsi highlands. The results also show that CFAs increase the quality of malt barley grown by contract farmers by an average of $40 \%$ as compared to the sample average. Higher yield, quality, and variable costs of production lead to higher malt barley net income.

(b) Malt barley commercialization Our results reveal that participation in a CFA positively influences smallholders' commercialization in the malt barley sector. We find that participation in a CFA leads to an increase in the share of produced malt barley that is commercialized and a higher farm gate price. The share of malt barley that is commercialized is significantly higher for those with a contract, on average $18 \%$ points. The price is significantly higher for those with a contract, on average 208 ETB per quintal. CFAs increase the average price farmers receive for their malt barley by $25 \%$ compared to the sample average. The effect on farm gate prices is most likely associated with improved quality.

Table 3 Average treatment effects using IPWRA

\begin{tabular}{|c|c|c|c|c|}
\hline \multirow{2}{*}{$\begin{array}{l}\text { Performance } \\
\text { indicators }\end{array}$} & \multicolumn{2}{|c|}{ Mean outcome } & \multirow{2}{*}{$\begin{array}{l}\text { Difference } \\
\text { (ATT) }\end{array}$} & \multirow{2}{*}{$\begin{array}{l}\% \\
\text { change }\end{array}$} \\
\hline & Contract & Non-contract & & \\
\hline Yield & 19.41 & 18.75 & $3.34(0.98)^{* * *}$ & 17.81 \\
\hline Price & 993 & 822 & $208(22.7)^{* * *}$ & 25.36 \\
\hline Share sold & 0.66 & 0.52 & $0.18(0.06)^{* * *}$ & 34.61 \\
\hline Cost & 4702 & 3920 & $946(84)^{* * *}$ & 24.13 \\
\hline Net income & 13009 & 10755 & $4829(1317)^{* * *}$ & 45.01 \\
\hline Product quality & 2.5 & 2.07 & $0.83(0.099)^{* * *}$ & 40.09 \\
\hline Other crops income & 11809 & 7575 & $4811(2112)^{* *}$ & 63.51 \\
\hline
\end{tabular}

Source: Field survey, 2015; standard errors in parentheses; ${ }^{* *} P<0.01,{ }^{* *} P<0.05,{ }^{*} P<0.10$ 
Table 4 Average treatment effects using PSM

\begin{tabular}{|c|c|c|c|c|c|}
\hline \multirow{2}{*}{$\begin{array}{l}\text { Performance } \\
\text { indicators }\end{array}$} & \multirow[t]{2}{*}{ Naive $t$ test } & \multicolumn{3}{|l|}{ PSM } & \multirow{2}{*}{$\begin{array}{l}\text { Critical } \\
\text { level of } \\
\text { hidden } \\
\text { bias }(\Gamma)\end{array}$} \\
\hline & & NNM & KBM & RM & \\
\hline Yield & $2.86(0.8) * * *$ & $2.40(1.45)^{*}$ & $2.38(1.38)^{*}$ & $2.76(1.33)^{* *}$ & $1.4-1.5$ \\
\hline Price & $184(10)^{* * *}$ & $206(22.72)^{* * *}$ & $198(23)^{* * *}$ & $207(22)^{* * *}$ & $3.0-3.1$ \\
\hline Share sold & $0.21(0.033)^{* * *}$ & $0.17(0.072)^{* *}$ & $0.16(0.067)^{* *}$ & $0.16(0.065)^{* *}$ & $2.4-2.5$ \\
\hline Costs & $809(71)^{* * *}$ & $839(101)^{* * *}$ & $845(143)^{* * *}$ & $850(135)^{* * *}$ & $3.0-3.1$ \\
\hline Net income & $4542(1027)^{* * *}$ & $3864(2062)^{*}$ & $5004(2505)^{* *}$ & $4502(2046)^{* *}$ & $2.8-2.9$ \\
\hline Product quality & $0.71(06)^{* * *}$ & $0.78(09)^{* * *}$ & $0.78(12)^{* * *}$ & $0.78(11)^{* * *}$ & $3.0-3.1$ \\
\hline Other crops income & $6452(1615)^{* * *}$ & $6974(2932)^{* *}$ & $7168(2688)^{* *}$ & $6534(2602)^{* *}$ & $1.5-1.6$ \\
\hline
\end{tabular}

Source: Field survey, 2015; Standard errors in parentheses; ${ }^{* *} P<0.01,{ }^{* *} P<0.05,{ }^{*} P<0.1$

(c) Income We find that participation in a CFA has a positive effect on farm family income. We find that a CFA leads to a higher malt barley net income, on average 4829 ETB per ha. This is crucial effect, which implies that participation in a CFA increases malt barley net income by $45 \%$ in comparison to the sample average. Our results also reveal that CFA participation leads to an increase in other crops' gross income, on average 4811 ETB per ha. This implies that participation in a CFA increases the farmer's income from other crop production by $64 \%$ compared to the sample average. There may be a significant spillover from CFA benefits into the production of food crops such as food barley and wheat, the major staples in the research area, probably due to modern inputs usage and technical assistance.

\section{Robustness check}

We assess the robustness of IPWRA estimates by comparing them with the results of PSM. The results for the PSM are presented in Table 4. The PSM approach produces almost similar results as the estimates shown in Table 3. We conducted two tests to examine the quality of matching process in PSM. First, on the observable factors, the credibility of the PSM procedure is evaluated using the covariates balancing test (Tables 6 and 7 in the Appendix). Using pseudo- $R^{2}$ values, we assessed the extent of systematic differences in covariates between contract and non-contract farmers after matching. Our results show that the pseudo- $\mathrm{R}^{2}$ reduced from 0.241 before matching to a range of 0.07-0.08 after matching (Table 7 in the Appendix). This low value indicates that after matching, there was no systematic difference in the distribution of covariates between the two groups. The chi-square test for pseudo- $\mathrm{R}^{2}$ is also insignificant after matching. Thus, the matching process is successful with regard to balancing the distribution of covariates between contract and non-contract farmers.

Second, we assessed the sensitivity of the ATT estimates to unobserved heterogeneity or hidden bias. In the PSM technique, selection to treatment is only based on observed characteristics, and it does not control for hidden bias due to unobserved factors (Caliendo and Kopeinig 2008). Heterogeneity may arise when contract and noncontract farmers differ on unobserved variables that simultaneously influence assignment to treatment and the outcome variable. We checked this using the bounding approach (Rosenbaum 2002). This method relies on the sensitivity parameter gamma 
(log-odds ratio) that determines how strong an unobservable variable must be to influence the selection process so as to bias the results (DiPrete and Gangl 2004). Following DiPrete and Gangl (2004) and Girma and Gardebroek (2015), we consider various critical gamma value levels. We reported the results of rbound tests in Table 4, last column. It indicates that the estimates of ATT are robust to hidden bias due to unobserved factors, even to the extent that would triple $(\Gamma=3) \log$ odds of differential assignment to treatment (Table 4).

\section{Discussion}

The literature on CFAs in emerging economies shows a debate on whether CFAs improve smallholders' income and production efficiency. Several empirical studies document a positive impact of CFAs, particularly in high-value chains, while there is also evidence that CFAs have negative income effects. In addition, CFAs are criticized for favoring large-sized farms at the expense of smallholders. Some authors have claimed that CFAs exclude the participation of resource-poor farmers (Otsuka et al. 2016; Weatherspoon and Reardon 2003). We will now discuss our findings within this larger debate on the pros and cons of CFAs.

On the effectiveness of CFAs, the results of our study are in agreement with previous findings about the positive impact of contract farming on farmers' income. Our findings demonstrate that CFA participation has a positive impact on the following performance indicators: malt barley yield, intensification, quality, share sold, farm gate price, malt barley income, and other crops income. Contract farmers achieved better performance in all of these indicators. For example, a CFA increases malt barley yield by $13 \%$, input costs by $19 \%$, farm gate prices by $22 \%$, and net income by $31 \%$ compared to sample average. Our result is consistent with CFA literature both in high-value chains and domestic food chains (Maertens and Vande Velde 2017; Mishra et al. 2016; Mishra et al. 2018; Wang et al. 2014a). This strong positive outcome is attributed to the improved technologies, technical assistance, and coordination introduced in the malt barley supply chain.

Foreign brewers introduced quality-based pricing and the use of a grading system, which resulted in quality upgrading. For instance, CFAs increase the farm gate prices that farmers receive by $22 \%$ compared to the sample average. This finding is in line with the results reported by Maertens and Vande Velde (2017) that rice contract farming in Benin increases farm gate prices by $11 \%$, and by Miyata et al. (2009), that vegetable contract farming for supermarkets in China increases farm gate prices by $8 \%$. Similar results are also reported from Nepal lentil sector (Mishra et al. 2018).

On the determinants of CFA participation, our findings show mixed evidence. Contrary to the results of Wainaina et al. (2014), we found a positive relationship between household education and the likelihood of participation in CFA. Similar positive effects of education on CFA participation have been reported for ginger farmers in Nepal (Kumar et al. 2016) and avocado farmers in Kenya (Mwambi et al. 2016). Education, as an indicator of human capital, enables households to understand information and take decisions on modern technologies and quality issues. It may also lead to more entrepreneurship and increased aspiration about the future of households' farming business. However, Girma and Gardebroek (2015) and Miyata et al. (2009) have reported that 
education has no significant effect and a negative effect on CFA participation in Ethiopia and China, respectively.

Our results also reveal that having a mobile phone, access to credit, and access to public extension services are positively related with participation in CFAs. With regard to a mobile phone, similar results have been reported by Mishra et al. (2016) and Kumar et al. (2016). Our result are also in line with the findings reported by Ma and Abdulai (2016) and Mwambi et al. (2016), who have shown a positive relationship between access to credit and CFA participation. However, Wainaina et al. (2014) report that access to credit has no significant effect on participation. In addition, Kariuki and Loy (2016) and Girma and Gardebroek (2015) have reported that extension services positively and significantly influence CFA participation. Contrary to this, Wainaina et al. (2014) have reported that access to extension services is negatively related with CFA participation.

The positive association between access to credit and CFA participation could be explained insofar that farmers who are able to access credit, tend to invest in the production of malt barley that meets the buyer's quality requirements, which can then earn them premium prices. That extension service is an important determinant could be because households who have good extension contacts, are better able to access useful information regarding benefits of modern agricultural technologies and marketing schemes.

Furthermore, we find that distance to markets and off-farm income negatively relate with CFA participation. Similar results have been reported by Miyata et al. (2009) for apple farmers in China, Wainaina et al. (2014), for poultry farmers in Kenya, and Mwambi et al. (2016) for avocado farmers in Kenya. The pattern observed could be explained in that breweries prefer to work with nearby farmers for reasons of logistics, monitoring, provision of technical assistance, and farm visits. Thus, a larger distance to the main road (or market) increases the transaction cost of sourcing malt barley from smallholders. Contrary to this, Maertens and Vande Velde (2017) reported a positive effect of distance to markets on the likelihood of farmers' participation in rice CFAs in Benin. Our results also show that off-farm income negatively affects the likelihood of participation in CFAs. This may be because smallholders specialized in farming (with fewer off-farm activities) are more likely to join CFAs. However, Azumah et al. (2016) and Wainaina et al. (2014) report that the likelihood of CFA participation increases with off-farm income. They argue that farmers' access to finance from off-farm activities improves their ability to buy basic inputs, which increases their probability of CFA participation.

\section{Conclusions}

The paper is a novel contribution to the few empirical studies analyzing the impact of CFAs within domestic (staple) food chains using robust econometric methods, with correction of selection bias. The paper examined the factors that influence farmers' decision to participate in a CFA, as well as the impact of CFA participation on intensification of production, commercialization and prices, and on farmer income in malt barley chains of Ethiopia. The study utilized cross-sectional survey data of malt barley farmers collected from the Arsi highlands of Ethiopia. 
Our empirical findings demonstrate the positive impacts of CFAs on all selected outcome indicators. We find that CFAs result in intensification of malt barley production, increased commercialization of malt barley, higher farm gate prices, increased net malt barley income, and higher income from other crops. Our estimated results are robust, consistent across different matching methods and OLS regression. Our findings imply that CFAs in a value-chain context lead to higher smallholder farm income. In addition, promoting CFAs and its interlinkage with POs might be an effective way to increase smallholder commercialization, intensification of barley production, and quality improvement in the value chain. Previous studies on the impact of CFAs mainly focused on high-value and exportoriented chains, while studies on domestic and staple food chains are few. Our study, thus, contributes to the agribusiness and development literature through providing empirical evidence on CFAs in domestic food chains.

Consistent with literature, our results reveal that contracting in domestic and local food chains can be beneficial for smallholder producers. This seems against the expectation, as expressed by Maertens and Vande Velde (2017) that contracting in domestic food chains is not feasible due to contract-enforcement problems that stem from a low value of produce and a large number of buyers in the chain. Three arguments could be forwarded why CFAs work in barley value chains. First, low side selling could be related to a high premium price of $22 \%$ that contract farmers received. Second, involvement of a PO may have a positive impact on the sustainability of the CFA. Third, linked to the current development policy paradigm-from-aid-to-trade-the role of NGOs has changed from providing generic farming support toward sub-contracting specific supply chain activities.

The findings have several important implications for policymakers and stakeholders involved in the transformation and development of food systems. The study provides empirical evidence on how multinationals influence upgrading of food chains and commercialization of smallholders in Africa. It also indicates that supporting CFAs in the malt barley chains is an effective way to contribute to reaching the government aim of expansion and intensification of malt barley production and quality upgrading. Public support on capacity building of POs also helps smallholder linkages to modern chains and the smooth functioning of contract arrangements. A major constraint for the expansion of contract production is the poor condition of the physical infrastructure such as the lack of all-season roads. The brewery companies only have contracts with POs close to the district towns.

Our findings encourage further research on the following issues. First, we have not addressed the impact of malt barley production on food security. Does malt barley production compete with food barley production? Second, it would be worthwhile to carry out a within-country comparison of impact of CFAs in staple-food chains and export-oriented chains. In particular, such research should focus on contract attributes in the two distinct chains and the implications for key actors including smallholders. 


\section{Appendix}

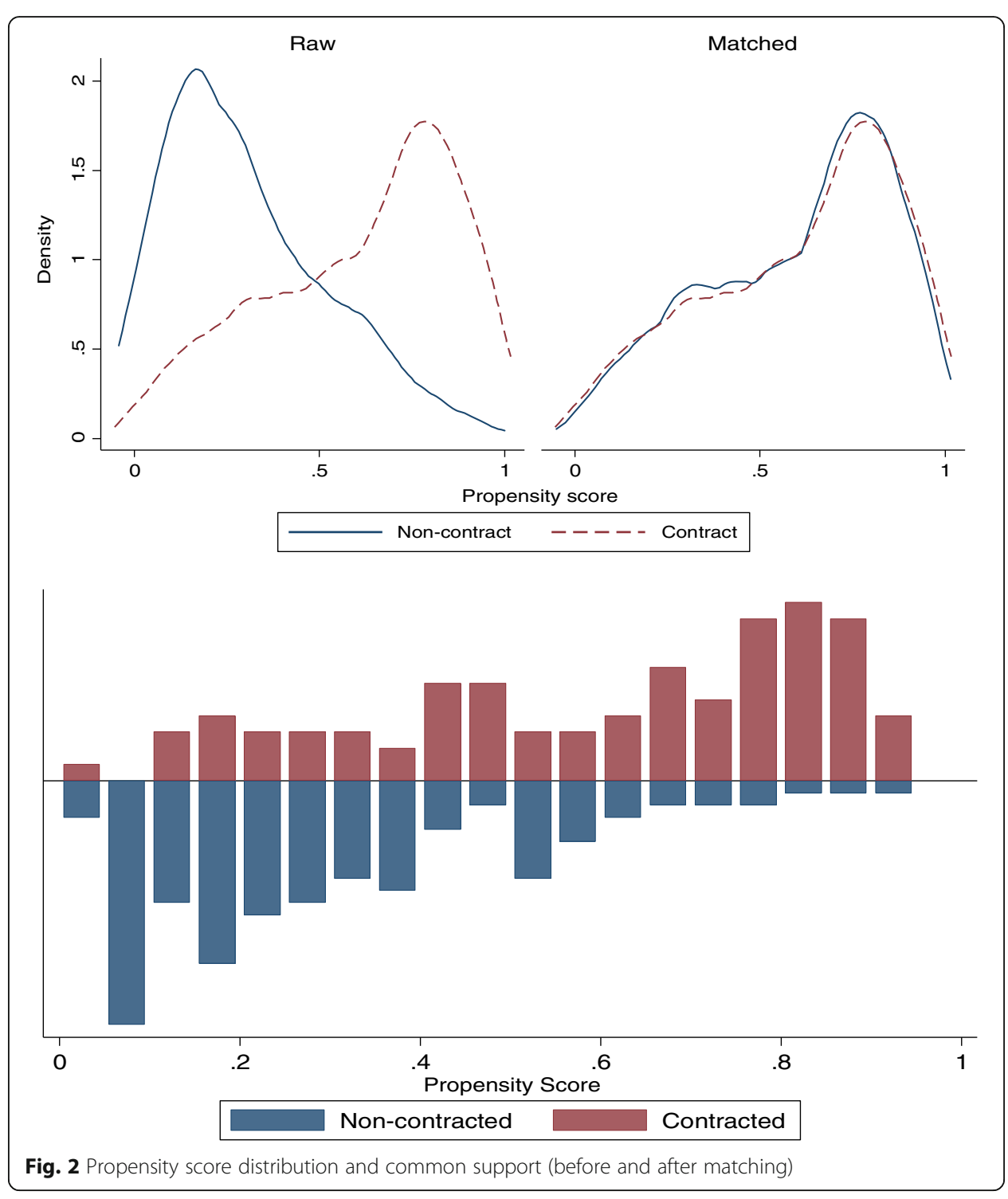


Table 5 Effect of CFA on intensification

\begin{tabular}{lllll}
\hline Indicators of intensity & Contract & Non-contract & t-stat & Sig. \\
\hline Improved seeds (0-1) & 1.0 & 0.39 & 13.2 & $* * *$ \\
Quantity of fertilize-DAP (qt) & 2.6 & 1.6 & 4.24 & $* * *$ \\
Quantity of fertilizer-NPS (qt) & 1.96 & 1.65 & 1.09 & \\
Quantity of fertilizer-Urea (qt) & 0.48 & 0.45 & 0.41 & \\
Cost of seed (ETB/ha) & 1245 & 799 & 44.62 & $* * *$ \\
Cost of fertilizer (ETB/ha) & 1307 & 1280 & 5.94 & $* * *$ \\
Cost of weeding (ETB/ha) & 620 & 380 & 12.75 & $* * *$ \\
Cost of harvesting (ETB/ha) & 709 & 571 & 4.04 & $* * *$ \\
Total variable costs (ETB/ha) & 4803 & 3994 & 11.33 & $* * *$ \\
\hline
\end{tabular}

Source: field survey, $2015 ;{ }^{* * *}$ significant at $1 \%$ level

Table $6 t$ tests for equality of means for each variable before and after the match

\begin{tabular}{|c|c|c|c|c|c|c|}
\hline \multirow[t]{2}{*}{ Variable } & \multirow[t]{2}{*}{ Sample } & \multicolumn{2}{|l|}{ Mean } & \multirow{2}{*}{$\begin{array}{l}\% \\
\text { bias }\end{array}$} & \multirow{2}{*}{$\begin{array}{l}\text { \% reduction } \\
\text { (bias) }\end{array}$} & \multirow{2}{*}{$\begin{array}{l}t \text { test } \\
p>|t|\end{array}$} \\
\hline & & Contract & Non-contract & & & \\
\hline \multirow[t]{2}{*}{ Age head } & Unmatched & 44.39 & 43.692 & 6.1 & & 0.667 \\
\hline & Matched & 44.39 & 43.107 & 11.1 & -83.0 & 0.473 \\
\hline \multirow[t]{2}{*}{ Family size } & Unmatched & 6 & 6.359 & -14.3 & & 0.318 \\
\hline & Matched & 6 & 5.747 & 10.0 & 29.7 & 0.463 \\
\hline \multirow[t]{2}{*}{ Working labor } & Unmatched & 3.59 & 3.837 & -13.7 & & 0.340 \\
\hline & Matched & 3.59 & 3.447 & 8.0 & 42.0 & 0.550 \\
\hline \multirow[t]{2}{*}{ Education head } & Unmatched & 5.79 & 4.837 & 23.9 & & 0.057 \\
\hline & Matched & 5.79 & 6.117 & -10.7 & 60.2 & 0.446 \\
\hline \multirow[t]{2}{*}{ Farm size } & Unmatched & 2.64 & 2.859 & -9.5 & & 0.514 \\
\hline & Matched & 2.64 & 2.802 & -7.0 & 26.1 & 0.607 \\
\hline \multirow[t]{2}{*}{ Malt barley area } & Unmatched & 0.75 & 0.735 & 1.9 & & 0.898 \\
\hline & Matched & 0.75 & 0.648 & 15.1 & -711.3 & 0.297 \\
\hline \multirow[t]{2}{*}{ Farming experience } & Unmatched & 22.99 & 21.650 & 11.1 & & 0.432 \\
\hline & Matched & 22.99 & 22.047 & 7.8 & 29.7 & 0.620 \\
\hline \multirow[t]{2}{*}{ Total livestock } & Unmatched & 9.06 & 8.849 & 2.4 & & 0.868 \\
\hline & Matched & 9.06 & 8.674 & 4.4 & -82.9 & 0.768 \\
\hline \multirow[t]{2}{*}{ Off-farm income } & Unmatched & 3.24 & 5.299 & -21.1 & & 0.144 \\
\hline & Matched & 3.24 & 2.719 & 5.3 & 74.8 & 0.670 \\
\hline \multirow[t]{2}{*}{ Distance to market } & Unmatched & 6.18 & 8.170 & -67.9 & & 0.000 \\
\hline & Matched & 6.18 & 7.145 & -33.0 & 51.4 & 0.011 \\
\hline \multirow[t]{2}{*}{ Mobile ownership } & Unmatched & 0.81 & 0.675 & 30.2 & & 0.035 \\
\hline & Matched & 0.81 & 0.862 & -12.8 & 57.7 & 0.323 \\
\hline \multirow[t]{2}{*}{ Access to credit } & Unmatched & 0.17 & 0.094 & 22.6 & & 0.105 \\
\hline & Matched & 0.17 & 0.352 & -53.7 & -137.6 & 0.006 \\
\hline \multirow[t]{2}{*}{ Extension contact } & Unmatched & 0.61 & 0.427 & 37.8 & & 0.008 \\
\hline & Matched & 0.61 & 0.574 & 7.9 & 79.2 & 0.603 \\
\hline
\end{tabular}


Table 7 Matching quality test: balancing property

\begin{tabular}{lllll}
\hline & $\begin{array}{l}\text { Before } \\
\text { matching }\end{array}$ & \multicolumn{2}{l}{ After matching (algorithms) } \\
\cline { 3 - 5 } & NNM $^{*}$ & 0.073 & KBM & RM \\
\hline Pseudo- ${ }^{2}$ & 0.241 & 17.3 & 0.081 & 0.080 \\
LR X2 & 67.59 & 0.188 & 19.1 & 18.9 \\
P value & 0.000 & 14.1 & 0.120 & 0.127 \\
Mean bias & 20.4 & 11.6 & 14.5 & 15.1 \\
Median bias & 14.3 & 9.0 & 12.1 \\
\hline
\end{tabular}

Note: * seven nearest is used

\section{Abbreviations}

IPWRA: Inverse probability-weighted regression adjustment; PSM: Propensity score matching; CFA: Contract farming arrangement; PO: Producer organization; PPP: Public private partnership; AMF: Assela malt factory; NGO: Nongovernment organization

\section{Acknowledgements}

We are grateful to the many smallholders, farmer cooperatives, and other stakeholders in the malt barley supply chains that shared their knowledge and experience with us.

\section{Authors' contributions}

First author contributes on survey design, data organization and analysis, and writing the manuscript. While the second author read, edit, and structure the manuscript. The authors read and approve the final manuscript.

\section{Funding}

This work was financially supported by the Netherlands Ministry of Economic Affairs, and Business Management \& Organization Group of Wageningen University. We thank both institutions for their contribution and support.

Availability of data and materials

Data will be available upon request.

\section{Declarations}

\section{Competing interests}

Both authors declare that they have no competing interests.

\section{Author details}

${ }^{1}$ European Commission Joint Research Center, Ispra, Italy. ${ }^{2}$ Department of Agricultural Economics, Hawassa University, P.O. Box 05, Hawassa, Ethiopia. ${ }^{3}$ Business Management and Organization Group, Wageningen University, P.O. Box 8130 6700, EW, Wageningen, The Netherlands.

Received: 12 November 2020 Revised: 15 April 2021

Accepted: 1 June 2021 Published online: 13 July 2021

\section{References}

Abebe GK, Bijman J, Kemp R, Omta O, Tsegaye A (2013) Contract farming configuration: smallholders' preferences for contract design attributes. Food Policy 40:14-24. https://doi.org/10.1016/j.foodpol.2013.01.002

Andersson Cl, Chege CG, Rao EJ, Qaim M (2015) Following up on smallholder farmers and supermarkets in Kenya. American Journal of Agricultural Economics 97(4):1247-1266. https://doi.org/10.1093/ajae/aav006

Azumah, S.B., Donkoh, S.A., Ansah, I.G.K., 2016. Contract farming and the adoption of climate change coping and adaptation strategies in the northern region of Ghana. Environment, Development and Sustainability, 1-21.

Bang H, Robins JM (2005) Doubly robust estimation in missing data and causal inference models. Biometrics 61(4):962-973. https://doi.org/10.1111/j.1541-0420.2005.00377.x

Barrett CB, Bachke ME, Bellemare MF, Michelson HC, Narayanan S, Walker TF (2012) Smallholder participation in contract farming: comparative evidence from five countries. World Development 40(4):715-730. https://doi.org/10.1016/j. worlddev.2011.09.006

Becker SO, Ichino A (2002) Estimation of average treatment effects based on propensity scores. The Stata Journal 2(4):358377. https://doi.org/10.1177/1536867X0200200403

Bellemare MF (2012) As you sow, so shall you reap: the welfare impacts of contract farming. World Development 40(7):14181434. https://doi.org/10.1016/j.worlddev.2011.12.008

Bellemare MF (2015) Contract farming: what's in it for smallholder farmers in developing countries? Choices 30:1-4

Bernard T, Spielman DJ (2009) Reaching the rural poor through rural producer organizations? A study of agricultural marketing cooperatives in Ethiopia. Food Policy 34(1):60-69. https://doi.org/10.1016/j.foodpol.2008.08.001

Bijman J, Muradian, R, Schuurman J (2016) Cooperatives, economic democratization and rural development. Edward Elgar Publishing.

Bolwig S, Gibbon P, Jones S (2009) The economics of smallholder organic contract farming in tropical Africa. World Development 37(6):1094-1104. https://doi.org/10.1016/j.worlddev.2008.09.012 
Briones RM (2015) Small farmers in high-value chains: binding or relaxing constraints to inclusive growth? World Development 72:43-52. https://doi.org/10.1016/j.worlddev.2015.01.005

Caliendo M, Kopeinig S (2008) Some practical guidance for the implementation of propensity score matching. Journal of Economic Surveys 22(1):31-72. https://doi.org/10.1111/j.1467-6419.2007.00527.x

CSA (2015) Area and production of major crop, agricultural sample survey. Central Statistical Agency (CSA) of Ethiopia, Addis Ababa, Ethiopia

Dedehouanou SF, Swinnen J, Maertens M (2013) Does contracting make farmers happy? Evidence from Senegal. Review of Income and Wealth 59:S138-S160. https://doi.org/10.1111/roiw.12041

DiPrete TA, Gangl M (2004) Assessing bias in the estimation of causal effects: Rosenbaum bounds on matching estimators and instrumental variables estimation with imperfect instruments. Sociological methodology 34(1):271-310. https://doi. org/10.1111/j.0081-1750.2004.00154.x

Dries L, Germenji E, Noev N, Swinnen JF (2009) Farmers, vertical coordination, and the restructuring of dairy supply chains in Central and Eastern Europe. World Development 37(11):1742-1758. https://doi.org/10.1016/j.worlddev.2008.08.029

FAO (2013a) Contract farming for inclusive market access. In: Food and Agriculture Organization of the United Nations (FAO). Italy, Rome

FAO (2013b) Smallholder integration in changing food markets. In: Food and Agriculture Organization of the United Nations (FAO). Italy, Rome

Girma J, Gardebroek C (2015) The impact of contracts on organic honey producers' incomes in southwestern Ethiopia. Forest Policy and Economics 50:259-268. https://doi.org/10.1016/j.forpol.2014.08.001

Jia X, Bijman J (2014) Contract farming: synthetic themes for linking farmers to demanding markets. In: Rankin M (ed) Da silva, C.A. Contract farming for inclusive market access FAO, Rome, pp 21-38

Kariuki IM, Loy JP (2016) Contractual farming arrangements, quality control, incentives, and distribution failure in Kenya's smallholder horticulture: a multivariate probit analysis. Agribusiness 32(4):547-562. https://doi.org/10.1002/agr.21462

Kebebe $E$ (2017) Household nutrition and income impacts of using dairy technologies in mixed crop-livestock production systems. Australian Journal of Agricultural and Resource Economics 61(4):626-644. https://doi.org/10.1111/1467-8489.12223

Kumar A, Roy D, Tripathi G, Joshi PK, Adhikari RP (2016) Can contract farming increase farmers' income and enhance adoption of food safety practices? Evidence from remote areas of. Nepal, International Food Policy Research Institute (IFPRI), South Asia Office

Ma W, Abdulai A (2016) Linking apple farmers to markets: determinants and impacts of marketing contracts in China. China Agricultural Economic Review 8(1):2-21. https://doi.org/10.1108/CAER-04-2015-0035

Maertens M, Minten B, Swinnen J (2012) Modern food supply chains and development: evidence from horticulture export sectors in sub-Saharan Africa. Development Policy Review 30(4):473-497. https://doi.org/10.1111/j.1467-7679.2012.00585.x

Maertens M, Swinnen JF (2012) Gender and modern supply chains in developing countries. The Journal of Development Studies 48(10):1412-1430. https://doi.org/10.1080/00220388.2012.663902

Maertens M, Vande Velde K (2017) Contract-farming in staple food chains: the case of rice in Benin. World Development 95: 73-87. https://doi.org/10.1016/j.worlddev.2017.02.011

McCullough EB, Pingali PL, Stamoulis KG (2008) Small farms and the transformation of food systems: an overview. In: E. McCullough, P.P., and K. Stamoulis (Ed.), The transformation of agri-food systems: globalization, supply chains and smallholder farmers, ed. Earthscan, London, pp 3-46

Michelson H, Reardon T, Perez F (2012) Small farmers and big retail: trade-offs of supplying supermarkets in Nicaragua. World Development 40(2):342-354. https://doi.org/10.1016/..worlddev.2011.07.013

Minot, N., 1986. Contract farming and its effect on small farmers in less developed countries Michigan State University, Department of Agricultural, Food, and Resource Economics (Working paper No. 31), East Lansing, MI.

Minot, N., Sawyer, B., 2016. Contract farming in developing countries: theory and practice, and policy implications, in: A. Devaux, M.T., J. Donovan, D. Horton (Ed.), Innovation for inclusive value-chain development: successes and challenges. International Food Policy Research Institute (IFPRI), Washington, D.C., pp. 127-158.

Minten B, Randrianarison L, Swinnen JFM (2009) Global retail chains and poor farmers: evidence from Madagascar. World Development 37(11):1728-1741. https://doi.org/10.1016/j.worlddev.2008.08.024

Minten B, Tamru S, Engida E, Kuma T (2016) Transforming staple food value chains in Africa: the case of teff in Ethiopia. The Journal of Development Studies 52(5):627-645. https://doi.org/10.1080/00220388.2015.1087509

Mishra AK, Kumar A, Joshi PK, D'Souza A (2016) Impact of contracts in high yielding varieties seed production on profits and yield: the case of Nepal. Food Policy 62:110-121. https://doi.org/10.1016/j.foodpol.2016.05.005

Mishra AK, Kumar A, Joshi PK, D'Souza A (2018) Impact of contract farming on yield, costs and profitability in low-value crop: evidence from a low-income country. Australian Journal of Agricultural and Resource Economics 62(4):589-607. https:// doi.org/10.1111/1467-8489.12268

Miyata S, Minot N, Hu D (2009) Impact of contract farming on income: linking small farmers, packers, and supermarkets in China. World Development 37(11):1781-1790. https://doi.org/10.1016/j.worlddev.2008.08.025

Mwambi MM, Oduol J, Mshenga P, Saidi M (2016) Does contract farming improve smallholder income? The case of avocado farmers in Kenya. Journal of Agribusiness in Developing and Emerging Economies 6(1):2-20. https://doi.org/10.1108/JA DEE-05-2013-0019

Narayanan S (2014) Profits from participation in high value agriculture: evidence of heterogeneous benefits in contract farming schemes in Southern India. Food Policy 44:142-157. https://doi.org/10.1016/j.foodpol.2013.10.010

Otsuka K, Nakano Y, Takahashi K (2016) Contract farming in developed and developing economies. Annual Review of Resource Economics 8:53-76

Oya C (2012) Contract farming in sub-Saharan Africa: a survey of approaches, debates and issues. Journal of Agrarian Change 12(1):1-33. https://doi.org/10.1111/j.1471-0366.2011.00337.x

Poulton C, Dorward A, Kydd J (2010) The future of small farms: new directions for services, institutions, and intermediation. World Development 38(10):1413-1428. https://doi.org/10.1016/j.worlddev.2009.06.009

Rashid S, Gashaw TA, Solomon L, Nicholas M (2015) The Barley Value Chain in Ethiopia. International Food Policy Research Institute (IFPRI). Addis Ababa, Ethiopia 
Reardon T, Barrett CB, Berdegué JA, Swinnen JF (2009) Agrifood industry transformation and small farmers in developing countries. World Development 37(11):1717-1727. https://doi.org/10.1016/j.worlddev.2008.08.023

Rosenbaum PR (2002) Observational studies Springer New York. https://doi.org/10.1007/978-1-4757-3692-2

Rosenbaum PR, Rubin DB (1983) The central role of the propensity score in observational studies for causal effects. Biometrika 70(1):41-55. https://doi.org/10.1093/biomet/70.1.41

Roy D, Thorat A (2008) Success in high value horticultural export markets for the small farmers: the case of Mahagrapes in India. World Development 36(10):1874-1890. https://doi.org/10.1016/j.worlddev.2007.09.009

Royer A, Bijman J, Abebe GK (2017) Cooperatives, partnerships and the challenges of quality upgrading: a case study from Ethiopia. Journal of Co-operative Organization and Management 5(1):48-55. https://doi.org/10.1016/j.jcom.2017.04.001

Simmons P, Winters P, Patrick I (2005) An analysis of contract farming in East Java, Bali, and Lombok, Indonesia. Agricultural Economics 33(s3):513-525. https://doi.org/10.1111/j.1574-0864.2005.00096.x

Singh S (2002) Contracting out solutions: political economy of contract farming in the Indian Punjab. World Development 30(9):1621-1638. https://doi.org/10.1016/S0305-750X(02)00059-1

StataCorp (2017) Stata treatment-effects reference manual: potential outcomes/counterfactual outcomes release 15. Texas Stata Press, College Station

Swinnen JF, Maertens M (2007) Globalization, privatization, and vertical coordination in food value chains in developing and transition countries. Agricultural Economics 37:89-102. https://doi.org/10.1111/j.1574-0862.2007.00237.x

Tefera DA., 2017. Foreign investment, organizational innovation and transformation in food supply chains: evidence from the Ethiopian barley sector. Ph.D. thesis, Wageningen University and Research. The Netherlands.

Ton G, Vellema W, Desiere S, Weituschat S, D'Haese M (2018) Contract farming for improving smallholder incomes: what can we learn from effectiveness studies? World Development 104:46-64. https://doi.org/10.1016/j.worlddev.2017.11.015

Verhofstadt E, Maertens M (2013) Processes of modernization in horticulture food value chains in Rwanda. Outlook on Agriculture 42(4):273-283. https://doi.org/10.5367/oa.2013.0145

Wainaina PW, Okello JJ, Nzuma JM (2014) Blessing or evil? Contract farming, smallholder poultry production and household welfare in Kenya. Quarterly Journal of International Agriculture 53:319-340

Wang H, Moustier P, Loc NTT (2014a) Economic impact of direct marketing and contracts: the case of safe vegetable chains in northern Vietnam. Food Policy 47:13-23. https://doi.org/10.1016/j.foodpol.2014.04.001

Wang HH, Wang Y, Delgado MS (2014b) The transition to modern agriculture: contract farming in developing economies. American Journal of Agricultural Economics 96(5):1257-1271. https://doi.org/10.1093/ajae/aau036

Weatherspoon DD, Reardon T (2003) The rise of supermarkets in Africa: implications for agrifood systems and the rural poor Development Policy Review 21(3):333-355. https://doi.org/10.1111/1467-7679.00214

Wendimu MA, Henningsen A, Gibbon P (2016) Sugarcane outgrowers in Ethiopia:"Forced" to remain poor? World Development 83:84-97. https://doi.org/10.1016/j.worlddev.2016.03.002

\section{Publisher's Note}

Springer Nature remains neutral with regard to jurisdictional claims in published maps and institutional affiliations.

\section{Submit your manuscript to a SpringerOpen ${ }^{\circ}$ journal and benefit from:}

- Convenient online submission

Rigorous peer review

- Open access: articles freely available online

- High visibility within the field

- Retaining the copyright to your article

Submit your next manuscript at $\boldsymbol{\nabla}$ springeropen.com 